\section{Anthocephalus cadamba extract shows hypoglycemic effect and eases oxidative stress in alloxan-induced diabetic rats}

\author{
Mohammad A. Alam, ${ }^{1}$ Nusrat Subhan, ${ }^{2}$ Sadia A. Chowdhury, \\ Mohammad A. Awal, ${ }^{3}$ Mahbub Mostofa, ${ }^{3}$ Mohammad A. \\ Rashid, ${ }^{4}$ Choudhury M. Hasan, ${ }^{4}$ Lutfun Nahar, ${ }^{5}$ Satyajit $D$. \\ Sarker $* 6$
}

${ }^{1}$ Department of Pharmacy, Stamford University, Dhaka, Bangladesh,

${ }^{2}$ Department of Pharmacy, Northern University, Dhaka, Bangladesh,

${ }^{3}$ Pharmacology Laboratory, Department of Pharmacology, Bangladesh Agricultural University, Mymensingh, Bangladesh,

${ }^{4}$ Faculty of Pharmacy, University of Dhaka, Bangladesh,

${ }^{5}$ Drug Discovery and Design Research Division, Department of Pharmacy, School of Applied Sciences, University of Wolverhampton, UK

${ }^{6}$ Department of Pharmacy, School of Applied Sciences, University of Wolverhampton, $U K$

\begin{abstract}
The hydroethanolic extract of the flowering tops of Anthocephalus cadamba (Roxb.) Miq., Rubiaceae, a Bangladeshi medicinal plant, was studied for its potential hypoglycemic effect and antioxidant property in alloxan-induced diabetic rats. The extract induced significant reduction in serum glucose, and transaminases, e.g. aspartate transaminase (AST), alanine transaminase (ALT) and alkaline phosphatases (ALP), activities. Significant changes in the thiobarbituric acid reactive substances (TBARS), peroxidase and catalase levels during the experimental period were also observed. The results established that the hydroethanolic extract of the flowering tops of $A$. cadamba possesses hypoglycemic property and is able to protect liver and brain from oxidative damages caused by diabetes.
\end{abstract}

Revista Brasileira de Farmacognosia Brazilian Journal of Pharmacognosy 21(1): 155-164, Jan./Feb. 2011

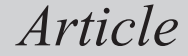

Received 7 Jul 2010

Accepted 26 Aug 2010 Available online 11 Mar 2011

Keywords: Anthocephalus cadamba Rubiaceae alloxan-induced oxidative stress diabetes

ISSN 0102-695X doi: $10.1590 / \mathrm{S} 0102-695 \mathrm{X} 2011005000033$

\section{Introduction}

An increased level of lipid peroxides and/ or oxidative stress is present in diabetic subjects, and may contribute to their increased risk of cardiovascular diseases (Haffner et al., 1995). Excessive production of free radicals is believed to be involved in many diabetic complications including diabetic neuropathy in diabetes mellitus (Sima \& Sugimoto, 1999). The neurological consequences of diabetes mellitus in the central nervous system (CNS) are now receiving greater attention. Glucose utilization is decreased in the brain during diabetes (McCall, 1992) providing a potential mechanism for increased vulnerability to acute pathological events. Effective therapeutic strategies to prevent or delay the development of this damage remain limited and the American Diabetes Association recommended that antioxidant therapy needs to be improved; either older antioxidants such as vitamin E, lipoic acid, and $N$-acetylL-cysteine need to be reformulated, or newer antioxidants have to be identified (Evans et al., 2003).

Anthocephalus cadamba (Roxb.) Miq. [Syn.
Neolamarckia cadamba (Roxb.) Bosser], Rubiaceae, is widely distributed throughout Bangladesh, Nepal, India, Myanmar, Sri Lanka, the Philippines, Indonesia, and Papua New Guinea (Banerji, 1977; 1978; Sahu et al., 2000; Niranjan et al., 2000; GRIN Databases, 2010). Various parts of this plant have traditionally been used as an antidiuretic, in the treatment of fever, anemia and tumor, and for the improvement of semen quality (Umachigi et al, 2007; Dr. Duke's Phytochemical and Ethnobotanical Databases, 2010). The leaves are recommended as a gargle to treat stomatitis (Slkar et al., 1992). This plant is traditionally used in the form of a paste by a tribe in Western Ghats for treating skin diseases. The bark extract has also been reported to be traditionally used as a hypoglycemic agent in Bangladesh (Ghani, 1998). While previous bioactivity studies on this plant revealed its analgesic, anti-inflammatory, antimicrobial, anti-oxidant, antimalarial, antihepatotoxic activities, and antidiarrheal and wound-healing properties (Umachigi et al., 2007; Alam et al., 2008a,b), the phytochemical investigations resulted in the isolation of indole alkaloids, secoiridoids, triterpenes and saponins from this plant (Banerji, 1977; 
1978; Brown \& Chapple, 1976; Kitagawa et al., 1996; Sahu et al., 1999; 2000).

In continuation of our phytochemical and pharmacological screening of Bangladeshi medicinal plants (Uddin et al., 2005, 2007a-c; Datta et al., 2007; Nayeem et al., 2006; Saha et al., 2007; Alam et al., 2008a,b; Mazid et al., 2009; Ara et al., 2010; Miah et al., 2010), we report on the hypoglycemic and oxidative stress-reducing activities of the hydroethanolic extract of the flowering tops of $A$. cadamba in alloxan-induced diabetic rats.

\section{Material and Methods}

\section{Plant material}

The flowering tops of Anthocephalus cadamba (Roxb.) Miq., Rubiaceae, were collected from Bangladesh Agricultural University campus in July 2005 and identified by the experts of the Botanical Garden of Bangladesh, Agricultural University and the National Herbarium, Mirpur, Dhaka, Bangladesh. Voucher specimens (BAUMAA-2005-AC1 and ACC. No 32497) for this collection have been retained in the herbarium of the Bangladesh Agricultural University, Mymensing, Bangladesh and the National Herbarium, Mirpur, Dhaka, Bangladesh, respectively.

\section{Extraction}

Shade-dried and powdered flowering tops of $A$. cadamba (200 g) were Soxhlet-extracted using 80\% aq. ethanol. The extract was concentrated by evaporation under reduced pressure at $40{ }^{\circ} \mathrm{C}$ using a Buchi rotary evaporator to yield a concentrate of reddish black extract (yield 6.32\%).

\section{Animals}

Swiss albino rats of both sexes, 3-4 weeks of age, weighing 120-130 g, were obtained from the Animal House of the International Centre for Diarrhoeal Disease and Research, Bangladesh (ICDDR, B). The animals were housed in five groups in stainless steel cages $(71 \times 56$ $\times 33 \mathrm{~cm}$ ) under standard laboratory conditions (relative humidity $55-65 \%$, r.t. $24.0 \pm 1.0{ }^{\circ} \mathrm{C}$ and $12 \mathrm{~h}$ light:dark cycle). Soft wood shavings were used as bedding of cages. Husk and excreta were removed from the cages every day. The animals were fed with pellets of rat feed provided by ICDDR, B, and fresh water ad libitum. The study involving rats was approved by the Ethical Review Committee (approval number: MAA0007) of the Department of Pharmacy, Stamford University, Dhaka, Bangladesh, and the experiments were carried out strictly in accordance with the guidelines provided by the World

\section{Health Organization.}

\section{Experimental design}

Experimental animals were divided into two lots; one for the glucose tolerance test (GTT) and the other for the long term effect of the extract on diabetic rats for a three weeks study periods.

In the glucose tolerance test fifteen non-diabetic rats of either sex were selected and grouped into three different groups. Group 1 served as the control group which received only normal saline. Group 2 and Group 3 received the extract of $A$. cadamba at the doses of 100 and $200 \mathrm{mg} / \mathrm{kg}$, respectively.

Another thirty rats were used for the long term effect of the extract on diabetic rats for a three weeks study periods. The rats were divided into five groups of six rats each. Group 1: normal rats; Group 2: diabetic control rats (alloxan, $150 \mathrm{mg} / \mathrm{kg}$, i.p.); Group 3: diabetic rats given glibenclamide ( $600 \mu \mathrm{g} / \mathrm{kg}$ body weight) in aqueous solution daily using an intragastric tube for three weeks; Group 4: diabetic rats given $A$. cadamba extract (200 $\mathrm{mg} / \mathrm{kg}$ body weight) in aqueous solution daily using an intragastric tube for three weeks; and Group 5: diabetic rats given $A$. cadamba ( $400 \mathrm{mg} / \mathrm{kg}$ body weight) in aqueous solution daily using an intragastric tube for three weeks.

The diabetic condition was assessed by determining the blood glucose concentration at three and five days after alloxan treatment. No detectable irritation or restlessness was observed after each drug or vehicle administration. No noticeable adverse effect (i.e., respiratory distress, abnormal locomotion and catalepsy) was observed in any animals after the drug administration.

\section{Glucose tolerance test}

Animals were fasted overnight and divided into three groups containing five rats each. Control animals (Group 1) were given $1 \mathrm{~mL}$ of distilled water orally. A. cadamba extract was given p.o. using a syringe at concentrations of 100 and $200 \mathrm{mg} / \mathrm{kg}$ body weight (Groups 2 and 3, respectively). After the administration of $A$. cadamba extract, all groups were given glucose (2 $\mathrm{g} / \mathrm{kg}$ bw) orally. Blood samples were collected from the tail vein just prior to and 30,60, 120 and $240 \mathrm{~min}$ after glucose loading. Serum glucose level was assayed by a glucometer. Results achieved from the glucose tolerance test were taken as a hypothetical reference to extrapolate the dose levels which would be used for evaluating shortand long-term effects of $A$. cadamba extract on diabetic rats. 
Blood sample collection

Blood samples were drawn at weekly intervals till the end of study (i.e. three weeks). At the end of the $3^{\text {rd }}$ week, all rats were sacrificed by decapitation (pentobarbitone sodium) anaesthesia (60 $\mathrm{mg} / \mathrm{kg})$. Blood was collected in two different tubes, one with anticoagulant- disodium EDTA for membrane stabilizing activity and the other without anticoagulant for serum separation. Serum was separated by centrifugation. After centrifugation, the clear supernatant was used for the assay of enzyme activities. The EDTA containing blood was washed three times with isotonic buffered solution (154 mM NaCl) in $10 \mathrm{mM}$ sodium phosphate buffer $(\mathrm{pH}$ 7.4). The blood was centrifuged each time for $10 \mathrm{~min}$ at $3000 \mathrm{rpm}$ and $\mathrm{RBC}$ was prepared for the membrane stabilizing activity.

\section{Brain sample collection}

Whole brain was immediately dissected out, washed in ice cold saline to remove blood. The brains were weighed and 10\% tissue homogenate was prepared with $0.025 \mathrm{M}$ Tris-HCl buffer, $\mathrm{pH}$ 7.5. After centrifugation at $2000 \mathrm{rpm}$ for $10 \mathrm{~min}$, the clear supernatant was used to measure thiobarbituric acid reactive substances (TBARS), hydroperoxides, nitric oxide (NO) level and catalase activity.

\section{Biochemical analysis}

\section{Estimation of blood glucose}

Glucose was measured in serum of non-fasted rats. Blood was sampled by tail tip method (Mallick et al., 2006) and thereafter analyzed with an auto analyzer Reflotron Plus (Roche, Germany) using commercial kit.

\section{Estimation of blood transaminase}

The serum was assayed for aspartate transaminase (AST), alanine transaminase (ALT) and alkaline phosphatases (ALP) with an auto analyser Reflotron Plus (Roche, Germany) using commercial kit (Alam et al., 2008).

\section{Estimation of lipid peroxidation}

Lipid peroxidation in brain was estimated colorimetrically by thiobarbituric acid reactive substances TBARS by the method previously described by Niehius \& Samuelsson (1968). In brief, $0.1 \mathrm{~mL}$ of tissue homogenate (Tris- $\mathrm{HCl}$ buffer, $\mathrm{pH}$ 7.5) was treated with $2 \mathrm{~mL}$ of $(1: 1: 1$ ratio) TBA-TCA-HCl reagent (thiobarbituric acid $0.37 \%, 0.25 \mathrm{~N} \mathrm{HCl}$ and
$15 \%$ TCA) and placed in water bath for $15 \mathrm{~min}$, cooled. The absorbance of clear supernatant was measured against reference blank at $535 \mathrm{~nm}$.

\section{Estimation of hydroperoxides}

Hydroperoxides level was estimated by the method described before by Jiang et al. (1992). Tissue homogenate $(0.1 \mathrm{~mL})$ was treated with $0.9 \mathrm{~mL}$ of Fox reagent ( $88 \mathrm{mg}$ butylated hydroxytoluene (BHT), 7.6 mg xylenol orange and $9.8 \mathrm{mg}$ ammonium iron sulfate were added to $90 \mathrm{~mL}$ of methanol and $10 \mathrm{~mL} 250 \mathrm{mM}$ sulfuric acid) and incubated at $37^{\circ} \mathrm{C}$ for $30 \mathrm{~min}$. The color developed was read at $560 \mathrm{~nm}$ colorimetrically. Hydroperoxides was expressed as $\mathrm{mM} / 100 \mathrm{~g}$ tissue.

\section{Assay of catalase}

Catalase was assayed colorimetrically at $620 \mathrm{~nm}$ and expressed as $\mu \mathrm{M}$ of $\mathrm{H}_{2} \mathrm{O}_{2}$ consumed $/ \mathrm{min} / \mathrm{mg}$ protein as described by Sinha (1972). The reaction mixture $(1.5$ $\mathrm{mL}$ ) contained $1.0 \mathrm{~mL}$ of $0.01 \mathrm{M} \mathrm{pH} 7.0$ phosphate buffer, $0.1 \mathrm{~mL}$ of tissue homogenate (supernatant) and $0.4 \mathrm{~mL}$ of $2 \mathrm{M} \mathrm{H}_{2} \mathrm{O}_{2}$. The reaction was stopped by the addition of $2.0 \mathrm{~mL}$ of dichromate-acetic acid reagent $5 \%$ potassium dichromate and glacial acetic acid were mixed in $1: 3$ ratio).

\section{Assay of nitric oxide (NO)}

The NO was determined according to the method described by Tracy et al. (1995) as nitrate and nitrite. In this study, Griess-Illosvoy reagent was modified by using naphthyl ethylene diamine dihydrochloride $(0.1 \% \mathrm{w} / \mathrm{v})$ instead of 1-napthylamine $(5 \%)$. The reaction mixture (3 $\mathrm{mL})$ containing brain homogenates $(2 \mathrm{~mL})$ and phosphate buffer saline $(0.5 \mathrm{~mL})$ was incubated at 25 ${ }^{\circ} \mathrm{C}$ for $150 \mathrm{~min}$. After incubation, $0.5 \mathrm{~mL}$ of the reaction mixture was mixed with $1 \mathrm{~mL}$ of sulfanilic acid reagent $(0.33 \%$ in $20 \%$ glacial acetic acid) and allowed to stand for $5 \mathrm{~min}$ for completing diazotization. Then, naphthyl ethylene diamine dihydrochloride $(1 \mathrm{~mL})$ was added, mixed and allowed to stand for $30 \mathrm{~min}$ at $25^{\circ} \mathrm{C}$. A pink colored chromophore was formed in diffused light. The absorbance of these solutions was measured at $540 \mathrm{~nm}$ against the corresponding blank solutions.

Hypotonic solution-induced diabetic rat erythrocyte hemolysis

Membrane stabilizing activity of the extract was assessed using hypotonic solution-induced rat erythrocyte hemolysis (Shinde et al., 1999a,b). The test sample consisted of stock erythrocyte (RBC) suspension $(0.50 \mathrm{~mL})$ mixed with $5 \mathrm{~mL}$ of hypotonic solution $(50$ 
$\mathrm{mM} \mathrm{NaCl}$ ) in $10 \mathrm{mM}$ sodium phosphate buffered saline (pH 7.4) containing the extract $(0.25-2.0 \mathrm{mg} / \mathrm{ml})$. The control sample consisted of $0.5 \mathrm{ml}$ of RBC mixed with hypotonic-buffered saline solution alone. The mixtures were incubated for $10 \mathrm{~min}$ at room temperature and centrifuged for $10 \mathrm{~min}$ at $3000 \mathrm{~g}$ and the absorbance of the supernatant was measured at $540 \mathrm{~nm}$. The percentage inhibition of hemolysis or membrane stabilization was calculated according to modified method described by Shinde et al. (1999a,b) and Umukoro \& Ashorobi (2006).

$$
\% \text { Inhibition of haemolysis }=100 \times\{\text { OD } 1-O D 2 / O D 1\}
$$

Where:

OD1: Optical density of hypotonic-buffered saline solution alone

OD2: Optical density of test sample in hypotonic solution

\section{Statistical analysis}

Data was analyzed by one way ANOVA using SPSS-12 for Windows. Differences in means were estimated by means of repetitive measures followed by Bonferroni and Dunnet's post hoc test and expressed as statistical mean \pm standard deviation. Differences between means were regarded significant at $p<0.05$.

\section{Results and Discussion}

Alloxan(2,4,5,6-tetra-oxohexahydropyrimidine) induces "chemical diabetes" in a wide variety of animal species by damaging the insulin secreting pancreatic beta cells, resulting in a decrease in endogenous insulin release (Lenzen \& Panten, 1988; Vijayvargia et al., 2000). In the present study hypoglycaemic activity of the hydroethanolic extract of A. cadamba was evaluated on non-diabetic and diabetic rat models. The glucose tolerance test using the non-diabetic rats showed a dose-dependent decrease of glucose in plasma after administration of the extract over $4 \mathrm{~h}$ (Table 1). The extract significantly decreased the blood glucose level and prevented the weight loss in alloxaninduced diabetic rats. The effect of the extract on body weight in alloxan-induced diabetic rats is shown in Table 2 .
Alloxan administration caused a significant weight loss after three weeks of treatment from $128.00 \pm 2.09$ to $107.83 \pm 5.41 \mathrm{~g}$, whereas rats in the normal group continued to put on weight. Treatment with 200 and $400 \mathrm{mg} / \mathrm{kg}$ doses of the extract reversed the weight loss. Serum glucose levels in normal rat group (Group 1) reached steady concentrations $73.17 \pm 2.48 \mathrm{mg} / \mathrm{dL}$ in the second week, and $75.50 \pm 1.52 \mathrm{mg} / \mathrm{dL}$ in the third week. On the other hand, a significant increase in serum glucose levels was observed in the diabetes control group (Group 2), $240.67 \pm 3.98$ and $241.33 \pm 2.55 \mathrm{mg} / \mathrm{dL}$ in the second and third week, respectively.

The glucose level in the glibenclamide treated group (Group 3) remained unchanged during the experimental period. Multi-dose study revealed that administration of the extract at the dose of $200 \mathrm{mg} / \mathrm{kg}$ reduced the elevated glucose level significantly in the second week after alloxan administration to $203.67 \pm 7.17$ $\mathrm{mg} / \mathrm{dL}$, and in the third week glucose level further decreased to $191.50 \pm 6.09 \mathrm{mg} / \mathrm{dL}$. The glucose lowering activity of the extract $(400 \mathrm{mg} / \mathrm{kg})$ began in the second week with a reduction of $158.67 \pm 6.56 \mathrm{mg} / \mathrm{dL}$, and reached to its maximum reduction in the third week by $110.67 \pm 5.75 \mathrm{mg} / \mathrm{dL}$. The extract displayed antidiabetic effect in a concentration dependent manner (Table 3), and the activity was quite similar to that of the glibenclamide treated group at a higher dose.

Oxidative stress, leading to an increased production of reactive oxygen species (ROS) as well as lipidperoxidation, increases in diabetes (Wolff, 1993) and also hyperglycemic animals (Liu et al., 1996). Similarly, oxidative damage in rat brain is increased by experimentally induced hyperglycemia (Aragno et al., 1997). It has been suggested that the modified oxidative state induced by chronic hyperglycemia may contribute to nervous tissue damage; free radical species impair the central nervous system, attacking neurons and schwann cells, and the peripheral nerves (Kawai et al., 1998; Kumar \& Menon, 1998; Aragno, 2000). Because of high polyunsaturated lipid content, schwann cells and axons are particularly sensitive to oxygen free radical damage; lipid peroxidation may increase cell membrane rigidity and impair cell function. Lipidperoxidation products are also increased in the brains of Type 1 diabetic rats (Makar et al, 1995) and Type 2 diabetic mice (Kumar \& Menon,

Table 1. Glucose tolerance test of the hydroethanolic extract of Anthocephalus cadamba (ACE) on non-diabetic rats

\begin{tabular}{lcccccc}
\hline \multirow{2}{*}{ Groups } & \multicolumn{5}{c}{ Glucose $(\mathrm{mg} / \mathrm{dL})$} \\
\cline { 2 - 6 } & $0 \mathrm{~h}$ & $1 \mathrm{~h}$ & $2 \mathrm{~h}$ & $3 \mathrm{~h}$ & $4 \mathrm{~h}$ \\
\hline Group 1 (Control) & $85.40 \pm 1.34$ & $83.80 \pm 1.64$ & $85.00 \pm 2.35$ & $80.80 \pm 2.68$ & $82.20 \pm 3.03$ \\
Group 2 (ACE 100 mg/kg) & $86.40 \pm 0.55$ & $68.20 \pm 3.77$ & $68.80 \pm 3.11$ & $72.60 \pm 1.14$ & $73.00 \pm 1.58$ \\
Group 2 (ACE 200 mg/kg) & $83.20 \pm 1.10$ & $57.20 \pm 3.03$ & $55.80 \pm 3.35$ & $55.60 \pm 4.97$ & $57.00 \pm 4.58$ \\
\hline
\end{tabular}

Values are represented as mean \pm standard deviation. Differences in means were estimated by means of repetitive measures followed by the Bonferroni and Dunnet's post hoc test $(\mathrm{n}=5)$. Statistical significance was considered as $p<0.05$ in all cases vs. control. 
Table 2. Effect of the hydroalcoholic extract of Anthocephalus cadamba (ACE) on body weight of rats.

\begin{tabular}{lccc}
\hline \multirow{2}{*}{ Group } & \multicolumn{3}{c}{ Body weight (in g) } \\
\cline { 2 - 4 } & $1^{\text {st }}$ week & $2^{\text {rd }}$ week & $3^{\text {rd }}$ week \\
\hline Group 1 Normal rats & $128.17 \pm 2.32$ & $129.83 \pm 2.86$ & $134.67 \pm 1.75$ \\
Group 2 Diabetes control & $128.00 \pm 2.09$ & $113.50 \pm 6.09$ & $107.83 \pm 5.41$ \\
Group 3 Glibenclamide & $127.50 \pm 2.88$ & $133.17 \pm 1.83$ & $137.83 \pm 1.94$ \\
Group 4 ACE 200 mg/kg & $127.83 \pm 1.94$ & $132.17 \pm 1.17$ & $134.33 \pm 1.51$ \\
Group 5 ACE 400 mg/kg & $128.33 \pm 2.06$ & $133.67 \pm 1.51$ & $138.17 \pm 1.47$ \\
\hline
\end{tabular}

Values are represented as mean \pm standard deviation. Differences in means were estimated by means of Repetitive measures followed by Bonferroni and Dunnet's post hoc test $(\mathrm{n}=5)$ Statistical significance was considered as $p<0.05$ in all cases vs. control.

Table 3. Effect of the hydroethanolic extract of $A$. cadamba (ACE) on blood glucose level in plasma.

\begin{tabular}{lccc}
\hline \multirow{2}{*}{ Group } & \multicolumn{3}{c}{ Blood glucose level (mg/dL) } \\
\cline { 2 - 4 } & $1^{\text {st }}$ week & $2^{\text {rd }}$ week & $73.17 \pm 2.48$ \\
\hline Group 1 Normal rats & $73.17 \pm 2.48$ & $73.17 \pm 1.52$ \\
Group 2 Diabetes control & $239.27 \pm 1.28$ & $240.67 \pm 3.98$ & $241.33 \pm 2.55$ \\
Group 3 Glibenclamide & $112.13 \pm 2.12$ & $118.83 \pm 2.64$ & $132.50 \pm 3.08$ \\
Group 4 ACE 200 mg/kg & $212.67 \pm 1.11$ & $203.67 \pm 7.17$ & $191.50 \pm 6.09$ \\
Group 5 ACE 400 mg/kg & $188.25 \pm 2.16$ & $158.67 \pm 6.56$ & $110.67 \pm 5.75$ \\
\hline
\end{tabular}

Values are represented as mean \pm standard deviation. Differences in means were estimated by means of Repetitive measures followed by Bonferroni and Dunnet's post hoc test $(\mathrm{n}=5)$. Statistical significance was considered as $p<0.05$ in all cases vs. control.

1998).

Diabetes and stress mediated increases in oxidative stress as well as decreases in antioxidant activity may make the brain more vulnerable to subsequent pathological events. The effects of the A. cadamba extract on brain oxidative parameters in alloxan-induced diabetes are shown in Table 4. The treatment with the extract ( 200 and $400 \mathrm{mg} / \mathrm{kg}$ ) over a period of three weeks produced a protective effect on the significantly decreased levels of lipid peroxidation product TBARS and NO. It also increased the activity of the enzyme peroxidase and catalase. TBARS and NO levels were found to be increased in diabetic animals, but decreased by the extract (200 and $400 \mathrm{mg} / \mathrm{kg}$ ). TBARS and hydroperoxides (lipid peroxidative markers) showed high lipidperoxidation. This could be due to the fact that the brain contains relatively high concentration of easily peroxidizable fatty acids (Carney et al., 1991). In agreement with previous studies (Kakkar et al., 1998), the induction of diabetes in rats with alloxan resulted in an increase in lipid peroxidation (TBARS), an indirect evidence of intensified free radical production. Most of the tissue damage is thought to be free-radicals mediated by attacking membranes through peroxidation of unsaturated fatty acids. The present findings showed increased lipid peroxidation in rats exposed to alloxan, and its attenuation by the oral administration of the $A$. cadamba extract at the doses of 200 and $400 \mathrm{mg} / \mathrm{kg}$. The antiperoxidative effect of the extract at the dose of $400 \mathrm{mg} / \mathrm{kg}$ exhibited more significant effect than that of glibenclamide. Significantly lower levels of lipid peroxides in brain of the extract treated diabetic rats and increased activities of enzymic and non-enzymic antioxidants in brain suggested that the extract reduced oxidative stress by quenching free radicals.

Catalase is a hemoprotein that catalyzes the reduction of hydrogen peroxides and protects the tissues from highly reactive hydroxyl radicals. Reduced activities of superoxide dismutase and catalase in liver and kidney were observed during diabetes, and implicated to deleterious effects due to the accumulation of $\mathrm{O}^{-2}$ and $\mathrm{H}_{2} \mathrm{O}_{2}$ (Searle \& Wilson 1980). Administration of the extract of $A$. cadamba increased the activity of these enzymes (Table 4) through free-radical-scavenging activity because of the presence of phenolic compounds in the extract (Niranjan et al., 2000).

Nitric oxide (NO) has been recognized as a biological neural messenger molecule although it is best known as a toxic reactive free-radical in the CNS. $\mathrm{NO}$ or NO-derived nitrogen oxides must interact with neuromodulators in order to modify these modulators, especially monoamines, and thereby change their regulatory action on synaptic transmission (Fossier et al. 1999). Thiol (-SH) containing enzymes and proteins are critical targets for $\mathrm{NO}$, so it forms relatively stable nitroso-thiols (-S-NO). Reduction of NO production may consequently result in a stimulation of oxidative phosphorylation and increase peripheral oxygen uptake (Kuo \& Schroeder, 1995). A critical reaction that NO undergoes in oxygenated biological media is a direct 
bimolecular reaction with $\mathrm{O}_{2}$ S- yielding peroxynitrite (ONOO-). Peroxynitrite and its further products have been linked to several interactions which may contribute to cellular injury, including lipid peroxidation, nitrosylation of some molecules, and inactivation of sodium channels. ONOO- has been shown to oxidize a variety of biological molecules and may be responsible for certain types of NOmediated toxicity (Szabo et al., 1995). Taking these facts together, NO or closely related molecules are considered to be neurodestructive. The positive correlation between NO and TBARS in the present findings might show the direct or indirect enhancer effect of NO on lipid peroxidation. Alloxan treated diabetic control group (Group 2) produced the highest amount of NO and TBARS among all groups, and the $A$. cadamba extract prevented the production of NO and TBARS (Table 4) in a dose-dependent manner.

Alloxan administration significantly increased liver function biomarkers, aspartate transaminase (AST), alanine transaminase (ALT) and alkaline phosphatases (ALP), in comparison with normal rats (Table 5). The extract at the concentrations of 200 and $400 \mathrm{mg} / \mathrm{kg}$ produced an inhibitory effect on elevated liver markers while the diabetes control group and dibenclamide treated group did not show any change in the elevated liver enzyme concentration. The AST and ALT activities are known as cytosolic marker enzymes reflecting hepatocellular necrosis as they are released into the blood after cell membrane damage. In the present study, therefore, both enzyme activities were used as indicators of hepatic damage. Table 3 shows the activities of AST and ALT in experimental rats. Compared with the normal rats, the diabetic rats showed more activities of serum AST and ALT. Further the histopathological study of the liver section confirmed the protection of the hepatic lesion after alloxan treatment (Figure 1).

The major pathological consequence of freeradical induced membrane lipid peroxidation includes increased membrane rigidity, decreased cellular deformability, reduced erythrocyte survival, and lipid fluidity (Kolanjiappan et al., 2002). Hunt et al. (1990) reported that glucose oxidation in the presence

Table 4. Effect of the hydroethanolic extract of Anthocephalus cadamba (ACE) on oxidative enzymes in plasma.

\begin{tabular}{lcccc}
\hline & \multicolumn{3}{c}{ Broup } & \multicolumn{3}{c}{ Brain homogenates of alloxan induced diabetic rat } \\
\cline { 2 - 5 } & $\begin{array}{c}\text { TBARS } \\
\mu \mathrm{M} / \mathrm{g} \text { tissue }\end{array}$ & $\begin{array}{c}\text { Peroxidase } \\
\mathrm{mM} / \mathrm{g} \text { of tissue }\end{array}$ & $\begin{array}{c}\text { CAT } \\
(\mathrm{U} / \mathrm{mg} \text { of protein) }\end{array}$ & $\begin{array}{c}\text { NO } \\
\mathrm{nM} / \mathrm{g} \text { of tissue }\end{array}$ \\
\hline Group 1 Normal rats & $3.11 \pm 0.87$ & $13.58 \pm 0.16$ & $9.01 \pm 0.49$ & $8.41 \pm 0.67$ \\
Group 2 Diabetes control & $15.61 \pm 0.49$ & $12.23 \pm 0.13$ & $6.77 \pm 0.48$ & $13.06 \pm 0.57$ \\
Group 3 Glibenclamide & $9.23 \pm 0.62$ & $16.34 \pm 0.12$ & $10.63 \pm 0.52$ & $10.02 \pm 0.69$ \\
Group 4 ACE 200 $\mathrm{mg} / \mathrm{kg}$ & $9.08 \pm 0.63$ & $15.07 \pm 0.23$ & $11.05 \pm 0.50$ & $11.01 \pm 0.36$ \\
Group 5 ACE 400 $\mathrm{mg} / \mathrm{kg}$ & $6.12 \pm 0.72$ & $17.12 \pm 0.21$ & $13.48 \pm 0.29$ & $10.07 \pm 0.34$ \\
\hline
\end{tabular}

Values are represented as mean \pm standard deviation. Differences in means were estimated by means of ANOVA followed by Bonferroni and Dunnet's post hoc test $(\mathrm{n}=5)$. Statistical significance was considered as $p<0.05$ in all cases vs control. Ua: $\mu \mathrm{mol}$ of $\mathrm{H}_{2} \mathrm{O}_{2}$ consumed/min.

Table 5. Effect of the crude hydroethanolic extract of Antocephalus cadamba (ACE) on liver enzyme in serum.

\begin{tabular}{lccc}
\hline \multicolumn{1}{c}{ Group } & $\begin{array}{c}\text { Mean Serum AST level } \\
(\mathrm{U} / \mathrm{L}) \pm \mathrm{SD}\end{array}$ & $\begin{array}{c}\text { Mean Serum ALT level. } \\
(\mathrm{U} / \mathrm{L}) \pm \mathrm{SD}\end{array}$ & $\begin{array}{c}\text { Mean Serum ALP level } \\
(\mathrm{U} / \mathrm{L}) \pm \mathrm{SD}\end{array}$ \\
\hline Group 1 Normal rats & $81.83 \pm 1.72$ & $34.50 \pm 1.97$ & $36.67 \pm 1.63$ \\
Group 2 Diabetes control & $140.50 \pm 5.24$ & $80.17 \pm 3.60$ & $58.33 \pm 3.33$ \\
Group 3 Glibenclamide & $93.33 \pm 3.14$ & $43.17 \pm 1.94$ & $42.50 \pm 3.27$ \\
Group 4 ACE 200 mg/kg & $101.33 \pm 6.18$ & $42.33 \pm 2.16$ & $39.17 \pm 2.04$ \\
Group 5 ACE 400 mg/kg & $85.17 \pm 2.14$ & $36.83 \pm 1.17$ & $34.33 \pm 1.63$ \\
\hline
\end{tabular}

Values are represented as mean \pm standard deviation. Differences in means were estimated by means of ANOVA followed by Bonferroni and Dunnet's post hoc test $(\mathrm{n}=5)$. Statistical significance was considered as $p<0.05$ in all cases vs control.

Table 6. Effect of the hydroethanolic extract of Antocephalus cadamba (ACE) on membrane stabilization of alloxan induced rats.

\begin{tabular}{lcc}
\hline Group & Absorbance & \% Protection \\
\hline Group 1: Normal & NA & NA \\
Group 2: Diabetes Control & $0.25 \pm 0.00$ & 16.34 \\
Group 3: Glibenclamide & $0.14 \pm 0.00$ & 53.91 \\
Group 4: ACE $200 \mathrm{mg} / \mathrm{kg}$ & $0.13 \pm 0.00$ & 57.59 \\
Group 5: ACE $400 \mathrm{mg} / \mathrm{kg}$ & $0.12 \pm 0.00$ & 60.73 \\
\hline
\end{tabular}

NA: Not applicable 
Anthocephalus cadamba extract shows hypoglycemic effect and eases oxidative

of transition metals result in excessive generations of reactive oxygen species, which in turn affect biomembrane structure and function by mediating lipid peroxidation process. The enhanced TBARS and the declined antioxidants observed in the erythrocytes of diabetic rats can therefore be attributed to the increased biomembrane lipidperoxidation process, and thereby contributing to alterations in antioxidants status. Previous investigations revealed that various herbal preparations could stabilize the red blood cells membrane and exert their anti-inflammatory activity (Sadique et al., 1989). Since the membrane of the red blood cell is similar to that of lysosomal membranes, the effect of drugs or extracts on human red blood cell membrane could be extrapolated to the stabilization of lysosomal membranes (Oyedapo \& Famurewa, 1995; Shinde et al., 1999a,b). The extract of $A$. cadamba significantly protected the erythrocyte hemolysis (Table 6) which could be attributed to its ability to scavenge free-radical and decrease the No and TBARS production.

These results suggested that the antidiabetic effect of $A$. cadamba flowering tops might be, at least in part, a consequence of increased glucose metabolism, and an increase in serum insulin concentration as a result of protection of the pancreas from free-radical damages induced by alloxan.
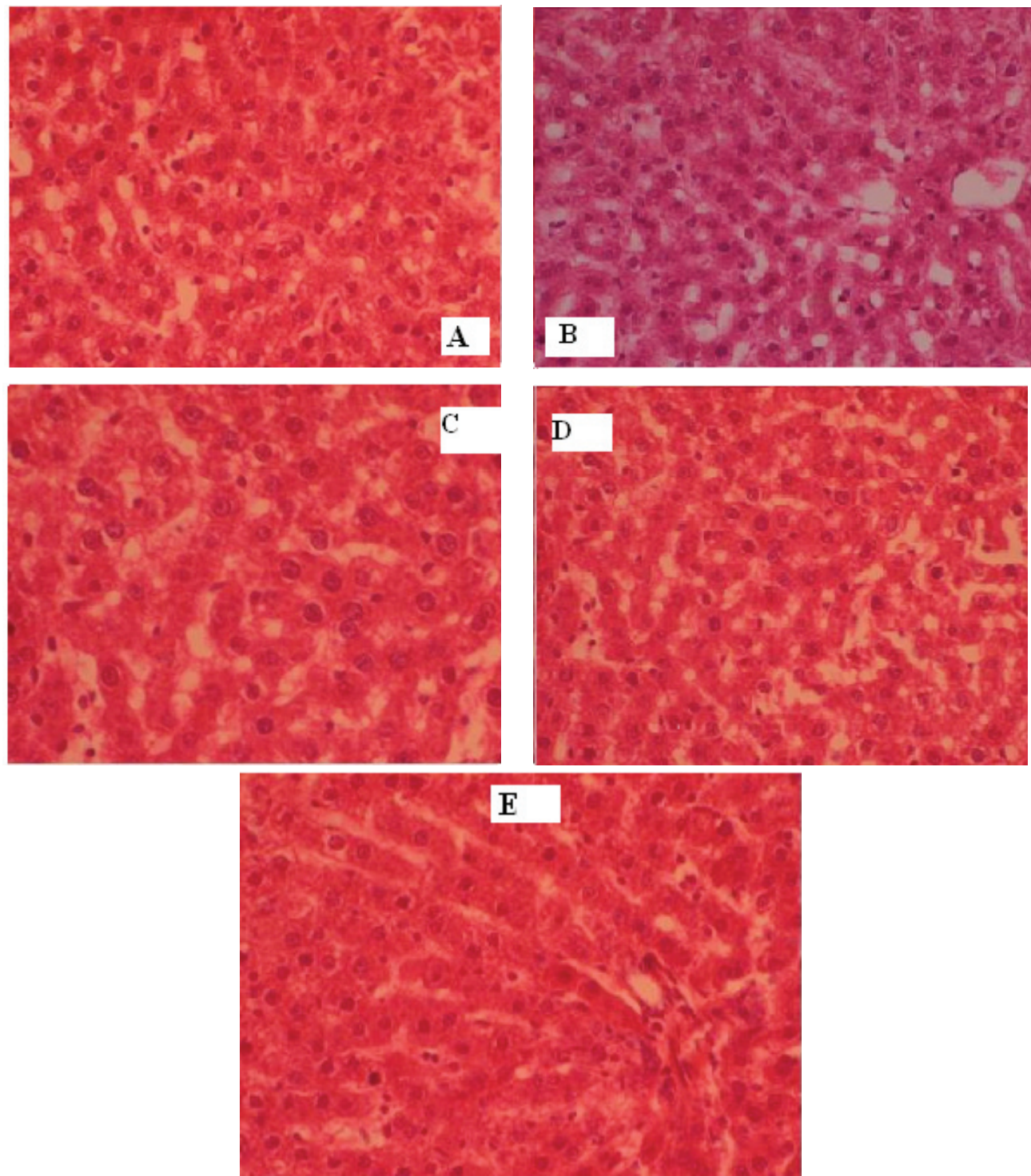

Figure 1. Typical photomicrograph of liver. A. Control group showing normal architecture of the hepatocyte; B. Diabetes control group having fatty degeneration and ballooning of the hepatocyte; C. Glibenclamide treating group also showing fat accumulation; D. Antocephalus cadamba $(200 \mathrm{mg} / \mathrm{kg})$ treating group sowing some fatty degeneration but relatively normal architecture; E. A. cadamba $(400 \mathrm{mg} / \mathrm{kg})$ treating group sowing relatively normal architecture of the hepatocyte in the surrounded acene. 


\section{Acknowledgements}

The authors acknowledge the technical support of the Laboratory of Physiology of the Department of Physiology through Associate Professor Kamrul Islam, Bangladesh Agricultural University, Mymensingh.

\section{References}

Alam MA, Ghani A, Subhan M, Rahman MM, Haque MS, Majumder MM, Majumder MEH, Akter RA, Nahar L, Sarker SD 2008a. Antioxidant and membrane stabilizing properties of the flowering tops of Anthosephalus cadamba. Nat Prod Comm 3: 65-70.

Alam MA, Akter R, Subhan N, Rahman MM, Majumder MM, Nahar L, Sarker SD 2008b. Antidiarrhoeal property of the hydroethanolic extract of the flowering tops of Anthocephalus cadamba. Rev Bras Farmacogn 18: 155159.

Ara A, Arifuzzaman M, Ghosh CK, Hashem MA, Ahmad MU, Bachar SC, Nahar L, Sarker SD 2010. Anti-inflammatory activity of Adenanthera pavonina in experimental animals. Rev Bras Farmacogn 20: 929-932.

Aragno M, Brignardello E, Tamagno O, Boccuzzi G 1997. Dehydroeppiandrosterone administration prevents the oxidative damage induced by acute hyperglycemia in rats, J Endocrinol 155: 233-240.

Aragno M, Parola S, Tamagno E, Brignardello E, Manti R, Danni O, Boccuzzi G 2000. Oxidative derangement in rat synaptosomes induced by hyperglycemia: restorative effect of dehydroepiandrosterone treatment. Biochem Pharmacol 60: 389-395.

Banerji N 1978. Structure of 2 new saponins from stem bark of Anthocephalus cadamba Miq, J Indian Chem Soc 55: 275-278.

Banerji N 1977. New saponins from stem bark of Anthocephalus cadamba Miq. Indian J Chem B 15: 654-655.

Brown RT, Chapple CL 1976. Anthocephalus alkaloids: cadamine and isocadamine. Tetrahedron Lett 19: 629-630.

Carney JM, Strake-Reed PE, Oliver CN, Landum RW, Chang MS, Wu JF, Floyd RA 1991. Reversal of age-related increase in brain protein oxidation, decrease in enzyme activity and loss in temporal and spatial memory by chronic administration of the spin trapping compound N-tert-butyl-a-pheynitrone. Proc Natl Acad Sci (USA) 88: 3633-3636.

Datta BK, Nahar L, Rahman MM, Gray AI, Auzi AA, Sarker SD 2007. Polygosumic acid, a new cadinane sesquiterpene, from Polygonum viscosum inhibits the growth of drugresistant Escherichia coli and Staphylococcus aureus (MRSA) in vitro. J Nat Med 61: 391-396.

Dr. Duke's Phytochemical and Ethnobotanical Database 2010. ARS, National Genetic Resources Program. Germplasm Resources Information Network - (GRIN), National Germplasm Resources Laboratory, Beltsville, Maryland.
Available on-line at http://www.ars-grin.gov/cgi-bin/ duke/ethnobot.pl.

Evans JL, Goldfine ID, Maddux BA, Grodsky GM 2003. Are oxidative stress-activated signaling pathways mediators of insulin resistance and $\beta$-cell dysfunction. Diabetes 52 : 1-8.

Fossier P, Blanchard B, Ducrocq C, Leprince C, Tauc L, Baux G 1999. Nitric oxide transforms serotonin into an inactive form and this affects neuromodulation. Neuroscience 93: $597-603$

Ghani A 2003. Medicinal Plant of Bangladesh with Chemical Constituents and Uses. $2^{\text {nd }}$ ed. Asiatic Society of Bangladesh. pp. 431-432.

GRIN Taxonomy Databases 2010. USDA, ARS, National Genetic Resources Program. Germplasm Resoures Information Network - (GRIN), National Germplasm Resources Laboratory, Beltsville, Maryland. Available on-line at http://www.ars-grin.gov/cgi-bin/npgs/html/ taxon.pl?3575.

Haffner SM, Agil A, Mykkanen L, Stern MP, Jialal I 1995. Plasma oxidizability in subjects with normal glucose tolerance and impaired glucose tolerance and NIDDM. Diabetes Care 18: 646-652.

Hunt JV, Smith CCT, Wolff SP 1990. Autoxidative glycosylation and possible involvement of peroxides and free radicals in LDL modification by glucose Diabetes 39: 14201424.

Jiang ZY, Hunt JV, Wolff SP 1992. Ferrous ion oxidation in the presence of xylenol orange for detection of lipid hydroperoxide in low density lipoprotein. Analytical Biochem 202: 384-389.

Kakkar R, Mantha SV, Radhi J, Prasad K, Kalra J 1998. Increased oxidative stress in rat liver and pancreas during progression of streptozotocin-induced diabetes. J Clin Sci 94: 623-632.

Kawai N, Keep RP, Betz AL, Nagao S 1998. Hyperglycemia induces progressive changes in the cerebral microvasculature and blood-brain barrier transport during focal cerebral ischemia. Acta Neurochir (Wien) 71: 219-221.

Kitagawa I, Wei H, Nagao S, Mahmud T. Hori K, Kobayashi M, Uji T, Shibuya H 1996. Indonesian medicinal plants. XIV. Characterisation of 3'-O-caffeoylsweroside, a new secoiridoid glucoside, and kelampayosides $\mathrm{A}$ and B, two new phenolic apiglucosides from the bark of Anthocephalus chinensis (Rubiaceae). Chem Pharm Bull 44: 1162-1167.

Kolanjiappan K, Manoharan S, Kayalvizhi M 2002. Measurement of erythrocytes lipids, lipid peroxidation, antioxidants and osmotic fragility in cervical cancer patients. Clin Chim Acta 326: 143-149.

Kuo PC, Schroeder RA 1995. The emerging multifaceted roles of nitric oxide. Ann Surg 221: 220-235.

Kumar JS, Menon VP 1993. Effect of diabetes on levels of lipid peroxides and glycolipids in rat brain. Metabolism 42: 
1435-1439.

Lenzen S, Panten U 1988. Alloxan: history and mechanism of action. Diabetologia 31: 337-342.

Liu J, Wang X, Shigenaga MK, Yeo HC, Mori A, Ames BN 1996. Immobilization stress causes oxidative damage to lipid, protein and DNA in the brain of rats, FASEB J 10: 15321538.

Makar TK, Hungund BL, Cook GA, Kashfi K, Cooper AJL 1995. Lipid metabolism and membrane composition are altered in the brains of Type II diabetic mice. J Neurochem 64: 2159-2168.

Mallick C, Maiti R, Ghosh D 2006. Comparative study on antihyperglycemic and antihyperlipidemic effects of separate and composite extract of seed of Eugenia jambolana and root of Musa paradisiaca in streptozotocin- induced diabetic male albino rat. Iranian $J$ Pharmacol Ther 5: 27-33.

Mazid MA, Datta BK, Nahar L, Bashar SMA, Bachar SC, Sarker SD 2009. Analgesic, anti-inflammatory and diuretic properties of Polygonum barbatum var. barbata. Rev Bras Farmacogn 19: 749-754.

McCall AL 1992. The impact of diabetes on the CNS. Diabetes 41: 557-570.

Miah MN, Bachar SC, Nahar L, Rahman MS, Rashid MA, Hadiuzzaman S, Sarker SD 2010. Composition of the volatiles of Citrus macroptera var. annamensis and evaluation of bioactivity. J Essential Oil Bear Pl 13: 211218.

Niehius WG, Samuelsson D 1968. Formation of malondialdehyde from phospholipids arachidonate during microsomal lipidperoxidation. Eur J Biochem 6: 126-130.

Niranjan P, Sahua KK, Zhonghua J, Banerjee S, Mandal NB, Nikaido T 2000. Triterpene glycosides from the bark of Anthocephalus cadamba. J Chem Res (S): 22-23.

Nyeem MAB, Alam MA, Awal MA, Mostofa M, Islam N, Uddin SJ, Rouf R 2006. CNS depressant effect of the crude methanolic extract of Rosa damascena on mice. Iranian J Pharmacol Ther 5: 171-174.

Oyedapo OO, Famurewa AJ 1995. Antiprotease and membrane stabilizing activities of extracts of Fagara zanthoxyloids, Olax subscorpioides and Tetrapleura tetraptera. Int $J$ Pharmacol 33: 65-69.

Saha A, Masud MA, Bachar SC, Kundu JK, Nahar L, Datta BK, Sarker SD 2007. Analgesic and anti-inflammatory activities of the extracts of Phyllanthus reticulatus in mice model, Pharm Biol 45: 355-359.

Sahu NP, Koike K, Jia ZH, Banerjee S, Mandal NB, Nikaido $\mathrm{T}$ 2000. Triterpene glycosides from the bark of Anthocephalus cadamba. J Chem Res (S): 22-23.

Sahu NP, Koike K, Jia ZH, Achari B, Banerjee S, Nikaido T 1999. Structure of two novel isomeriv triterpene saponins from Anthocephalus cadamba. Magn Reson Chem 37: 837742.

Searle AJ, Wilson R 1980. Glutathione peroxide effect of superoxide, hydroxyl and bromine free radicals on enzyme activity, Int J Radiat Biol 37: 213-217.

Sadique J, Al-Rqobah A, Bughith MF, EL-Gindy M 1989. The bioactivity of certain medical plants on the stabilizing of RBC membrane system. Fitoterapia 60: 525-532.

Sima AA, Sugimoto K 1999. Experimental diabetic neuropathy: An update. Diabetologia 42: 773-788.

Shinde U, Fu X, Inonye M 1999a. A pathway for conformational diversity in protein mediated by intramolecular chaperones. J Biol Chem 22: 15615-15621.

Shinde UA, Phadke AS, Nair AM, Mungantiwar AA, Dikshit VJ, Saraf VO 1999b. Membrane stabilizing activity - a possible mechanism of action for the anti-inflammatory activity of Cedrus deodara wood oil. Fitoterapia 70: 251-257.

Sinha KA 1972. Colorimetric assay of catalase, Anal Biochem 47: 389-394.

Slkar IV, Kakkar KK, Chakre OJ 1992. Glossary of Indian Medicinal Plants with Active Principles. CSIR, New Delhi, Part I, pp 75.

Szabo S, Salzman AL, Ischiropoulus H 1995. Endotoxin triggers the expression of an inducible isoform of nitric oxide synthase and the formation of peroxynitrite in the rat aorta in vivo. FEBS Lett 363: 235-238.

Tracy WR, Tse J, Carter G 1995. Lipopolysaccharide- induced changes in plasma nitrate and nitrite concentration in rats and mice: pharmacological evaluation of nitric oxide synthase inhibitors. J Pharmacol Exp Ther 272: 10111015.

Uddin SJ, Sjilpi JA, Alam SMS, Alamgir M, Rahman MT, Sarker SD 2005. Antidiarrhoeal activity of the methanol extract of the barks of Xylocarpus moluccensis in castor oil- and magnesium sulphate-induced diarrhoea models in mice. J Ethnopharmacol 101: 139-143.

Uddin SJ, Shilpi JA, Rouf R, Ferdous MM, Nahar L, Sarker SD 2007a. Neuropharmacological properties of Xylocarpus molucensis. Fitoterapia 78: 107-111.

Uddin SJ, Nahar L, Shilpi JA, Shoeb M, Borkowski T, Gibbons S, Middleton M, Byres M, Sarker SD 2007b. Gedunin, a limonoid from Xylocarpus granatum inhibits the growth of $\mathrm{CaCO}_{2}$ colon cancer cell line in vitro. Phytotherapy Res 21: 757-761.

Uddin SJ, Shilpi JA, Byres M, Middleton M, Shoeb M, Nahar L, Sarker SD 2007c. Swarnalin and cis-swarnalin, two new tetrahydrofuran derivatives with free radical scavenging activity, from the aerial parts of Cuscuta reflexa. Nat Prod Res 21: 663-668.

Umachigi SP, Kumar GS, Jayaveera KN, Kishore DVK, AshokKumar CK, Dhanpal R 2007. Antimicrobial, wound healing and antioxidant activities of Anthocephalus cadamba. African J Tradit Complement Altern Med 4: 481-487.

Umukoro S, Ashorobi RB 2006. Evaluation of anti-inflammatory and membrane stabilizing property of aqueous leaf extract of Momordica charantia in rats. African J Biomed Res 9: 119-124. 
Vijayvargia R, Monika K, Gupta S 2000. Hypoglycemic effect of aqueous extract of Enicostetmma littorale, Blume (Chhota chirayata) on alloxan induced diabetes mellitus in rats. Indian J Exp Biol 38: 781-784.

Wolff SP (1993) Diabetes mellitus and free radicals. Br Med Bull 49: 642-652.

\section{*Correspondence}

Satyajit D. Sarker

Department of Pharmacy, School of Applied Sciences, University of Wolverhampton, MM Building, Molineux Street, Wolverhampton WV1 1SB, West Midland, UK

s.sarker@wlv.ac.uk

Tel. +4401902322578 